\title{
The Image of a Woman of Colour and Native American Woman in Two Kerouac Novels: A Double Otherness
}

\begin{abstract}
The article examines the portrayal of a woman of colour in the novel The Subterraneans (1958), and the portrayal of a Native American woman in the novel Tristessa (1960). The two works are representative examples within the opus of the American writer Jack Kerouac (19221969), and offer suitable starting points for the reinterpretation of his attitude towards women and non-white ethnicities. The novels reveal the ethnocentric, even colonizing attitude of the dominating male narrator in relation to the dominated and subjugated social groups. Although the treated works are considered Kerouac's "female-centred novels" (Phelan Lyke 1991, v), this syntagm is problematized here by showing that the male narrator remains the true protagonist, focused essentially on his own perceptions of the non-white romantic subject, whereas the two female characters are (mere) objects for the protagonists' self-discovery, life experience and psychological projection. In this sense, Kerouac's consistent presentation of women as representatives of an identity of the exotic/Other reveals his nested gender and racial prejudice.
\end{abstract}

Keywords: Jack Kerouac; The Subterraneans; Tristessa; female characters; Otherness; colonialist discourse; racial prejudice; gender prejudice

\section{Podoba temnopolte in indijanske ženske $v$ dveh romanih Jacka Kerouaca: Dvojna drugost}

\section{POVZETEK}

Članek obravnava prikaz temnopolte ženske v romanu The Subterraneans (1958) in indijanske ženske v romanu Tristessa (1960). Omenjeni deli v opusu ameriškega pisatelja Jacka Kerouaca (1922-1969) predstavljata reprezentativna primera z nadvse prikladnimi iztočnicami za reinterpretacijo njegovega odnosa do žensk in pripadnikov drugih ras. V njiju se razkriva etnocentristični in celo kolonizatorski pogled dominirajočega moškega avtorskega pripovednega lika na dominirane in kolonizirane družbene skupine. Obravnavani deli veljata za Kerouacova "žensko orientirana romana" (Phelan Lyke 1991, v), vendar pa to sintagmo problematiziram, saj pravi protagonist romanov ostaja moški pripovedni lik, ki se v resnici osredotoča na lastno doživljanje nebelskih žensk, onidve pa sta (zgolj) objekta za protagonistovo samoodkrivanje in projekcijo njegovih lastnih idej nanju. Kerouacova prezentacija žensk kot predstavnic identitete drugega tako razkriva njegov spolni in rasni predsodek.

Ključne besede: Jack Kerouac; The Subterraneans; Tristessa; ženski liki; drugost; kolonialistični diskurz; rasni predsodek; spolni predsodek 


\section{Introduction}

In this article I employ the practice of the New Historicist Reading to analyse Kerouac's novels The Subterraneans and Tristessa, keeping in mind the methodological pluralism of new-historical interpretative praxis which draws from post-structuralist epistemology or the deconstructive reading of texts in superposition with their historical context. My academic contribution is an attempt to apply to Kerouac the new-historical praxis of Stephen Greenblatt and Catherine Gallager (2000), who in their treatment of literary texts and their contexts examine whether the discourse of a particular work of literature is concordant with its contextual discourses or not, or whether the text's discourse is monologic or dialogic in nature. The scholars posit that monologic texts are characterized by the exclusive expression of colonizing discourse, while dialogic texts engage in true differentiation or open heterogeneity of discourses. Greenblatt (1978) understands the monologic or dialogic state of discourse within the binary framing in the Foucauldian interpretation of power dynamics and attitudes to the Other. ${ }^{1}$ Greenblatt $(1990,23)$ transfers the Lacanian expression "discourse of the Other" to the field of colonial relations, using the term "linguistic colonialism". ${ }^{2}$ In his treatise Improvisation of Power (1978) he points out that hegemonic societal structures perpetuate the monologic totality, even in ways so deceptive as to absorb subversion itself, appropriating it to further strengthen the dominant ideology (cf. Matajc 2005, 100, and Kernev Štrajn 2001, 91).

New-historical readings are "sceptical, wary, demystifying, critical, and even adversarial" (Gallagher and Greenblatt 2000, 9), and I likewise maintain a critical and sceptical position in my reading of Kerouac's works, which are in literary history all too often unjustly lauded as revolutionary and counter-cultural (cf. McDowell 1966, 413; Gair 2007, 41; Charters 1986, 16; Škerl 42, 53) on account of their purported interest in, and engagement with, the struggles of marginalized social groups, and with resistance to the hegemonic ideology of the Western mainstream (Martinez 2003, 23-24). With a comparative analysis of the texts of Kerouac's novels alongside the author's biographical and socio-historical context, I thus establish that Kerouac's discourse is in fact colonialist, and even racist in its expression. I incorporate the ideas of Post-Colonial Theory, which likewise observe the differentiation or heterogeneity of discourses in relation to the Other. Elements of Feminist Criticism are employed to disclose Kerouac's evident androcentrism and machismo, his possessive and stereotypical depiction of women, their instrumentalization, and his consequent participation in the patriarchal ideology of the Western society of the United States of America in the 1950 s and 1960s.

\footnotetext{
In Foucault $(2001,80)$, the notion of discourse is closely connected to that of power relations or ideology, while its fundamental unit is the enunciation (l'énoncé), which to him carries the significance of an event, since it unites language and authority in the sense that mechanisms of power regulate discoursive production with their systems of exclusion (legal limitations, censorship, tabooization, stigmatization).

2 Jelka Kernev Štrajn $(2001,84)$ argues that Greenblatt later "likely unconsciously turned away from a [newhistorical] postcolonial orientation [...] and unwittingly assumed a position that allows colonial interpretation". I use the term colonialist discourse and refer to discourse in the "Foucauldian" sense as "systems of thoughts composed of ideas, attitudes, courses of action, beliefs and practices that systematically construct the subjects and the worlds of which they speak" (Lessa 2006, 283), though Keith Sawyer (2002, 435) claims that "Foucault's technical definition of the term 'discourse' does not include any of these senses".
} 
In those decades Kerouac's novels enchanted America with their openness, daring style, genuine language and the thematization of contemporary issues hitherto unexplored by the preceding generations of authors. Nevertheless, in the following decades scholarly readers were disappointed with the conclusions of their close treatment of Kerouac, finding themselves mired in his world of prejudice against women, homosexuals, ethnic minorities and, in general, Otherness as such. Mariana Des Forges (2015), for instance, posits that the novel $O n$ the Road represents a typical case of cultural imperialism. According to Des Forges, Kerouac's own apparent enthusiasm towards blacks and other minority cultures originated in his belief that the mainstream (dominant) culture was likewise oppressing him, finding faux-identification with - rather than a genuine interest in - their Otherness. She further points out that Kerouac essentially appropriated his entire Beat slang from black subcultures, and has been falsely credited with its origination, whereas his portrayal of people of colour is at best reductionist and filled with stereotypes and at worst even racist. In this article I will provide further support with a string of examples of colonialist discourse pervading the novels The Subterraneans (1958) and Tristessa (1960).

Similar disappointment over her re-reading of Kerouac was expressed by Linda McDowell (1996, 418), who writes: "what I once saw as a doomed resistance on the part of the Beats, I now tend to see as masculine selfishness". Indeed, we cannot overlook the markedly problematic treatment of female characters in Kerouac's works. Charters $(1986,74)$ posits most Beat Generation writers maintained similar attitudes towards women, as did the general male population of the 1950s and 1960s: they expected women to quietly listen while in male company, laugh and be pleasant, empathize, prepare food, wash the dishes and then excuse themselves to bed. Male authors were not particularly interested in the intellectual and artistic talents of their female companions. Kerouac himself, as a relatively conservative Catholic of French-Canadian heritage, was unable to radically distance himself from the conventions of the middle class and its patriarchal constitution. He chose women from underprivileged social environments, since he liked viewing himself as a saviour, a white knight of sorts, whereas his intentions were not the true emancipation of the "saved" female but rather an indulgent self-satisfaction over his own (quasi-)noble-mindedness. Kerouac's principles in the portrayal of female characters are analysed in detail by Phelan Lyke (1991, 4-5):

When Kerouac does write about his own relationship with a woman, he devotes an entire novel to it. The relationship exists in isolation, not as an integral part of his other adventures. [...] The autobiographical protagonist in each novel becomes obsessed with a woman; she consumes him, and he becomes very unhappy with his inability to control himself and the situation.

Kerouac does not consider women true intellectual equals to himself and his male colleagues. Though in The Subterraneans Mardou Fox is purported to be, to the first-person narrator Leo Percepied, the ideal of the genuine Beat or subterranean spirit, a companion in reading literature and conversing on the arts, her literary output and the work she does to survive do not interest him much at all - he remains focused squarely on his own creative activities, repeatedly returning to the house of his mother ("Mamère"), in the process of which Mardou is considered more or less a hindrance. Even worse: Leo gaslights her mental distress and 
anxiety, constantly framing it as minor compared to the experiences of her Native American father. In Tristessa, the female protagonist who gives the work its title is similarly an object for the projection of the narrator Jack Duluoz's ideas regarding her perceived sainthood, even her supposedly genuine Buddhism, while Jack shows more interest in his own hedonistic, escapist and colonialist (self)discovery in Mexico City - as an exotic space of Otherness than in Tristessa's severe existential struggles.

\section{Kerouac's Colonialist Discourse}

It is evident that Kerouac, on account of his whiteness, is not aware of his own inherent privileges within the mainstream (dominant, colonizing) culture and the deprivileged position of marginalized (dominated, colonized) cultures, since he tends to glorify the supposed authenticity of their outsider status with wilful ignorance as to the systemic structures of white oppression, operating especially against racial minorities. Kerouac actually laments how unfair it is he is unable to reach this coveted outsider status, since he is unwittingly granted the privileges of the social hierarchy in which he, as a heterosexual white middle-class male, occupies the top position (Des Forges 2015). It is abundantly clear Kerouac's interactions with minority underprivileged cultures are naive experiments in escapism from his mundane daily life of a middle-class American male. As a member of the dominant white culture, he receives a bastardized "authentic" counter-culture experience with the marginalized, with which he engages in a superficial way, instrumentalizing them for his own artistic production. Mariana Des Forges' critique (2015) is aimed against aggrandizing Kerouac as a celebrator of non-white cultures, as his work arguably showcases a complete ignorance of the position, significance and social history of marginalized communities. She claims Kerouac even stole the term "Beat" from the black culture of America - where it had signified dejection over social issues and existential struggles - and reinterpreted it for his own purposes, appropriating it from an expressive black cultural signifier into a fashionable counter-cultural trend of the white man; a further example of his deprecating attitude of "dominator over dominated" - even withholding from the latter the rights to their own signifiers on a wide platform, a typical characteristic of colonialist discourse.

Margaret Collopy (2016) similarly posits that while Kerouac, as a prominent figure of the counter-culture Beat Generation, does thematize marginalized life in America from proximity, his leaning on the movements of non-whites within the broader counter-culture movement is naive in the sense that it presents a romanticized view of the oppressed racial minorities suiting a particular hierarchical prism. To Kerouac, the marginalized American life is noble, captivating and pristine precisely on account of its constant daily struggle: he actually feels part of this struggle, which is a contrived voyeuristic notion.

Kerouac's romanticizing of Otherness is therefore reckless, narcissistic and filled with an undercurrent of racial prejudice. His discourse in relation to the marginalized minority culture is the discriminatory voice of the dominant colonizer (Panish 1994, 107). The reduction and instrumentalization of the personalities of racial and ethnic minorities in the United States for the purposes of his own fascination with Otherness as such and its artistic manifestations, reflect his ignorance of the Other as a fellow man of equivalent and equal 
value. He perceives Mexican Native Americans and people of colour as objects for his own escapist "experimentation", without a genuine ear for their social predicaments, culture or identity. Trudeau $(2011,294)$ points out that Kerouac entertains a notion of the "black spirit", that to him non-whites are as if unfamiliar entities from another world, to whom he attributes "mystical wisdom". Collopy (2016) on the other hand stresses Kerouac's simplistic conviction that marginalized social groups represent "the genuine essence of Beat". Kerouac's treatment of the marginalized is thus perversely (and blindly) colonizing: he celebrates them for their experience of oppression perpetuated precisely by the dominant, colonizing majority society (of which he is himself part), while displaying no insight into the underlying mechanisms of colonization.

Along this axis, Kerouac moves even further. As an admirer of jazz he takes for himself the right to the culture of the black musicians he associates with, extracting from this process a sense of superiority over the other whites who, as privileged conformists, cannot identify with his own "subterranean" sensibility: the capacity of appreciating and truly understanding black azz. He is even convinced that suffering somehow fosters a worthy artistic spirit, whereas the comfortable and privileged life cannot produce anything but a simulacrum of art (Collopy 2016). Collopy argues that the central problem of his myopic perspective is that it fails to recognize the fundamental divisions between his own personal experience and the cultures he delights in interacting with. His white privilege provides the luxury of choosing any particular lifestyle (he is able to return to his mother's home at will), whereas the marginalized non-whites are forced inexorably into their roles, or positions, by the social history of their people and the entrenched imbalances of power and class. In short, Kerouac is thoroughly ignorant of the unfairness of his status as a member of the dominant culture with regard to the truly underprivileged: with his attribution of the talent of black jazz musicians to some mystical consequence of their grave existential despair, and his unfair identification with these hardships, he robs them of their genuine experience, appropriating it for his own means.

Collopy (2016) concludes by stating that Kerouac's attitude towards marginalized social groups in the USA is concordant with the conventional attitudes of white men in the 1950s. It is reflected in his sense of racial and socio-economic superiority in relation to the oppressed, and his lack of empathy in building his career and identity from the appropriation and instrumentalization of other cultures - without being genuinely affected by the conditions of the oppressed in the midst of whom he seeks artistic refuge from the privileged status of the white American. He glorifies his own position and the position of the Beats by comparing it to the culture of the underprivileged groups, without awareness of the consequences of his disassociated cultural appropriation. His literary works fail to do justice to the lives of the minority groups, as they recurrently romanticize their suffering and lack of prospects as if there were something pristine and sacred about it, while appearing entirely oblivious to the socio-economic mechanisms underpinning and reproducing the social order. Kerouac is frivolous in his identification with the outcasts of America and his search for genuineness in the indigenous populations as his French-Canadian ("Canuck") descent lies radically removed and disengaged from the social margins proper, regardless of his own claims to the contrary. 
Jon Panish (1994, 107) establishes that Kerouac's representations of American racial minorities (Afro-Americans, Native Americans) are pervasively romanticized and reflect his fundamental lack of understanding of the Afro-American culture and social experience, drawing parallels with the viewpoints of the "romantic racists" from the 1840s and 1850s who perceived social minorities as "jovial, folk-wise and noble", a purported consequence of their victimhood or distress. Panish considers Kerouac among the many white authors who intentionally placed themselves outside the American social and literary mainstream, but states Kerouac was in fact no closer to the minority cultures than the previous generations of authors since his unwillingness to admit to the complexities of oppressed minority experience merely served to perpetuate racist ideologies.

I posit that Kerouac's colonialist discourse is also reflected in the novels I am addressing here. In the work Tristessa (1960), the first person narrator Jack Duluoz observes the destitute Mexican reality from the haughty perspective of a white Westerner, imagining himself to possess a clear insight (as opposed to his contemporaries) into the Otherness of the cultures he is immersing himself in, on account of some self-attributed outsiderhood:

I wish my relatives from Lowell were here to see how people and animals live in Mexico - [...] Everything is poor in Mexico, people are poor, and yet everything they do is happy and carefree, no matter what is - Tristessa is a junkey and she goes about it skinny and carefree, where an American would be gloomy - (Kerouac 1992, 29)

Similarly, he describes the slum of Mexico City: "incredibly dirty, staring streets full of dead dogs, past gawking children and old women in dirty rags, out of a field of rocks" (Kerouac 1992, 82). He sees Otherness as something exotic, without a realistic appraisal of the actual conditions and problems of the "exoticism" he is consuming: "I buy stinking livers" (Kerouac 1992, 39), "the whole of Mexico is a Bohemian Adventure" (Kerouac 1992, 40), "I fly by with one quick Walt Whitman look" (Kerouac 1992, 41). He enters the Mexican slum exhilarated, as if it were a safari:

[...] big Mamacita sits near the cocina pig pottery [...]. the whores are nooking the night with their crooking fingers of Come On, young men pass and give'em the once over, $[\ldots]$ long-legged brunettes in tight yellow dresses grab them and sock their pelvics in $[\ldots]$ - One look through the bar where the children gape and one through the whoreboy bar of queers where spidery heroes perform whore dances. (Kerouac 1992, 38-39)

During his cavorting across Mexico City, the narrator is intoxicated with copious amounts of morphine and whisky, or wine, or tequila, or pulque. He sketches Mexican children into his notebook, exchanging the drawing of portraits with a Mexican painter who notices "how young and beautiful and American I am" (Kerouac 1992, 70). He comments on the exoticism of the members of a choir led by "an old singer with his young disciple boy with thick sensitive lips and a big fat hostess woman as if out of Rabelais and Rembrandt Middle Ages" (Kerouac 1992, 71); the group's leader has a "red clay face, perfectly round and jocund, but Mexican owlish, with crazy eyes [...] and like always ecstatically happy" (Kerouac 1992, 71-72). In his accounts and interactions, the narrator maintains a self-important attitude, 
the conceit of a colonizer over a colonized people: he makes a toast to the police lieutenants, roguishly prodding "'Que es la vida?' [...]", admitting, even, that he has done this "to prove I'm philosophical and smart" (Kerouac 1992, 71). In his drunkenness he behaves arrogantly, distancing himself behind sunglasses, patronizing even the Mexican criminals: he tosses some cash "to a big fat guy and tell[s] him to go out and get some marijuana for the whole group" (Kerouac 1992, 71). Later he even throws money on the ground "to prove something" (Kerouac 1992, 72). The protagonist's haughty and disdainful attitude towards the Mexicans is implicitly expressed: "I don't care about money, I am the King of the World, I will lead your little revolutions myself" (Kerouac 1992, 72). He gloats at the thought the Mexican musicians hold him in high regard: "I take great pride meanwhile in showing how I appreciate the music, I even drum on the table" (Kerouac 1992, 72). Later, having realized he is completely broke, he calls the Mexicans "the gay gang of thieves" (Kerouac 1992, 73). His shocking ignorance of the real conditions of the Mexican underclasses shines through in his statements that continue to describe them as joyous, carefree, even ecstatic.

The situation is very similar in the novel The Subterraneans, too. Leo calls people of colour "the dark men of the dark coloured district" (Kerouac 2018, 71), attributing vitality and zest to the othered races without any awareness of their true social predicaments: "as I pass Mexicans I feel that great hepness I'd been having all summer on the street with Mardou my old dream of wanting to be vital, alive like a Negro or an Indian or a Denver Jap or a New York Puerto Rican came true" (Kerouac 2018, 82).

More than to blacks, he is drawn to Mardou's Native American father,

[...] the founder of her flesh and predecessor terror-ee of her terrors and knower of much greater flips and madness she in psychoanalytic-induced anxieties could ever even summon up to just imagine), formed just the background for thought about the Negroes and Indians and America in general but with all the overtones of 'new generation' and other historical concerns in which she was now swirled just like all of us in the Wig and Europe Sadness of us all, the innocent seriousness with which she told her story and I listened to so often and myself told - wide eyed hugging in heaven together - hipsters of America in the 1950s sitting in a dim room. (Kerouac 2018, 37-38)

The exoticizing and self-aggrandizing of his own quasi-understanding of the "Other" emerges as pretentious and entirely unjustified:

Concern for her father, because I'd been out there and sat down on the ground and seen the rail and steel of America covering the ground filled with the bones of old Indians and Original Americans. - In the cold grey fall in Colorado and Wyoming I'd worked on the land and watched Indian hoboes come suddenly out of brush [...] talking quietly to one another and so distant from the absorptions of the field hands, even the Negroes of Chayenne and Denver streets, the Japs, the general minority Armenians and Mexicans of the whole West that to look at a three-or-foursome of Indians crossing a filed and a railroad track is to the senses like something unbelievable as a dream - you think, 'They must be Indians'. (Kerouac 2018, 38) 


\section{Kerouac's Attitude Towards Women}

Kerouac's attitude towards women is in line with the typically macho and patriarchal societal relations of the 1950s America. Phelan Lyke (1991, 71-72) writes that the Beats habitually gathered in bars in male company, whereas women were allowed to join providing they were attractive enough and caused no disturbance. The Beats expected women to be fully employed so they could support their partners and children, yet admitted them no true intellectual or financial equality. The novel The Subterraneans depicts precisely this: Leo Percepied wishes to have fun with his friends, and his relationship with Mardou Fox is merely a hindrance. When they are in company together she appears redundant, apart from her role of exotic embellishment or symbol of personal prestige. The protagonist approves of her presence as long as she is modest and unassuming - when his friends grow interested in what she has to say, diverting their attention from Leo, he becomes resentful and petty, even slamming the door and walking away (Kerouac 2018, 85).

Joyce Johnson $(1983,79)$ claims that to the Beats, the woman was "a type rather than an individual" and that they therefore shaped female characters as "amalgams of several people". Overwhelmingly, the men considered their literary efforts more important than any female writing, as maintained the view women essentially did not possess comparable literary talent. Leo Percepied, Kerouac's alter ego in The Subterraneans (1958), might profess to idealize the "genuine Beat Generation essence" of Mardou Fox (Alene Lee), but in practice he is not particularly interested in her artistic endeavours. Leo mentions that Mardou reads Proust, Faulkner, Shakespeare and Cervantes, or that they discuss literature, yet he never thematizes her own writing. Front and centre is the protagonist's own artistic mission, he imagines himself a William Blake type, he and his wife in central London: "a bigtime 19th-century boss type dominant with women" (Kerouac 2018, 74). Naturally, Leo's relationship plans are traditionalist and egocentric: "'In fact baby, I'll be a famous man and you'll be the dignified wife of a famous man so don't worry”" (Kerouac 2018, 80).

Mardou's Beat spirit or "subterranean" nature ${ }^{3}$ enchants the narrator Leo Percepied, especially when he realizes he can love her "as a man", i.e. according to male standards. He yet appears drawn to the masculine traits in her, such as her walking at a manly pace, her penchant for rough-and-tumble play, her ability to bravely and defiantly describe her miserable childhood, her way of being at the same time "buddy-like" and "humble and meek, too, and a real woman" (Kerouac 2018, 78). He appreciates her intelligence, admiring her Bop sensitivity and her singing. And yet Leo perpetually stresses his own masculinity, even manliness, offering coquettish identification with his male readership: "I am crudely malely sexual and cannot help myself and have lecherous and so on propensities as almost all my male readers no doubt are the same" (Kerouac 2018, 23), in which his machismo is apparent. He is proud to possess Mardou, elated when Mac Jones (John Clellon Holmes) calls her "the child of Bop" (Kerouac 2018, 108) - it is then he realizes that Mardou elevates his prestige in male

The "subterranean" nature is to Kerouac an amalgamation of modernity, style, intellect, artistic talent and at the same time marginality, subculture: "They [the subterraneans] are hip without being slick, they are intelligent without being corny, they are intellectual as hell and know all about Pound without being pretentious or talking too much about it, they are very quiet, they are very Christlike." (Kerouac 2008, 21) 
company. Lipton $(1959,20)$ claims the only possibility for a woman to join the male Beats was through sharing their enthusiasm over music. It is precisely her interest in jazz that makes Leo appreciate Mardou: "she is the only girl I've ever known who could really understand bop and sing it" (Kerouac 2018, 79).

As soon as Mardou does not behave according to Leo's expectations, his machismo and misogyny are readily on display. Leo describes her as uncouth, rugged and lacking good manners: "she eats an orange, she makes a lot of noise sucking it" (Kerouac 2018, 65). When a party host accuses Mardou of stealing a pornographic photograph, Leo does not defend her before his raucous friends, contemplating instead her indecency, something he later characterizes as "my first foolish mistake in my life and love with Mardou" (Kerouac 2018, 54). It is then he also notices "the first of so many indignities piled on her, not on her capacity for suffering but gratuitously on her little female dignities" (Kerouac 2018, 54). He admits "I had my 'doubts' my male self-contained doubts about her, so reasoned" (Kerouac 2018, 58). He considers breaking up with her and finding "another girl, white, white things, etc." (Kerouac 2018, 58), but he does not wish to hurt her so as not to spoil her admiration of him (Kerouac 2018, 59). His attitude is more a wish for the discovery of the Beat/subterranean world through Mardou, and less an earnest interest in her as a person (Phelan Lyke 1991, 52), meaning he instrumentalizes her as an object or means to an end.

Leo's machismo is especially evident at the novel's ending, when he decides to renew his relationship with Mardou, understanding this won't be easy, but - being a proponent of machismo - nevertheless convinced that "always the man can make the little woman bend, she was made to bend" (Kerouac 2018, 114-15). When Mardou reveals her sexual affair with Yuri (Gregory Corso) to Leo he is incensed, saying he has "a big male right to leave her" (Kerouac 2018, 116). Retreat after an experience of escapism with a woman is a typical strategy of Kerouac; in modern terms he "ghosts"' his love subjects, fashioning them afterwards into artistic representations through the male gaze: as if social conventions always succeed in overpowering his wish for true subversive action.

Ann Charters $(1973,195)$ claims that the artistic process of The Subterraneans was to Kerouac far more emotionally gratifying than his romantic adventure with Alene Lee, and that he was in general more concerned about his writer's reputation among colleagues and readers than the collapse of his relationship. We might state in this regard that his writing was therapeutic: the misery of getting over Alene, provided he felt any in the first place, was resolved and channelled through the process of writing, which allowed him to set closure to a life episode and move on, on his own terms, a process of personal alchemy without any particular consequences to his wellbeing (Phelan Lyke 1991, 53).

In the novel, Mardou herself is aware that to the men a woman represents a trophy in the context of prestige and masculine competition. She tells Leo guys jostle and posture among themselves, and that the female is for them a "prize" in this contest (Kerouac 2018, 35). After she sleeps with Yuri, her value as a "prize" is in Leo's eyes dramatically diminished (Kerouac 2018, 117). The novel ends with Leo's telling words: that he had lost Mardou's love as a "prize",

Intimately engages with, then suddenly abandons the subject, cutting off all contact. 
and hence returned home (defeated) to write his "subterranean" novel (Kerouac 2018, 118). Consequently we may establish that Leo's love story with an unhappy ending is harnessed for the purposes of his writing, where Mardou becomes twice exploited and instrumentalized: first for the purpose of experimental experience, and then for the purpose of creative inspiration the artistic process of writing about the former. Leo considers himself a great and prolific genius deserving of "world-wide love" (Kerouac 2018, 28), for which it is essential to experience pain; or as he admits: "I wanted to both hurt and 'lacerate' myself" (Kerouac 2018, 29).

The real-life Mardou Fox (Alene Lee) recounted (Gifford and Lee 1978, 51) that she perceived those same events and people in a different light altogether compared to Kerouac's account. She states (Gifford and Lee 1978, 182) that women were attracted to Kerouac, and he was fond of them in turn, but that he was unable to support a dependent wife since it was he, in fact, who needed someone constantly looking after him. Nonetheless, Kerouac was in truth "conventional and stereotypical in his thinking" (Phelan Lyke 1991, 81). Carolyn Cassady $(1987,42)$ further comments that his alter ego in The Subterraneans is not strictly representative of the author's true character, since he was supposedly far less interested in sex than his autobiographical protagonist.

In Tristessa, we may observe Kerouac's portrayal of the non-sexual relationship of the narrator Jack Duluoz with the Mexican morphine addict Tristessa (a fictionalized Esperanza Villanueva), who is to him similarly exotic as Mardou Fox is to Leo Percepied in The Subterraneans (1958). Jack is attracted to Tristessa's provocative behaviour and unconventional aesthetics. He feels the need to court her, though she is more sexually experienced than him. He plainly describes Tristessa, who is of native Aztec heritage, as exotic (Kerouac 1992, 8). As a heavy addict, Tristessa is constantly under the influence of substances or ill (Kerouac 1992, 10). In her, Jack Duluoz seeks unconditional faith and love for others (Stephenson 1990, 33). While pursuing the relationship with Esperanza (in the summer of 1955), Kerouac lived in celibacy, committed temporarily to a Buddhist lifestyle. He projects his ideas on Tristessa, speculating she unconsciously already lives by the core Buddhist principles, something he infers from the perceived enlightened nature of her actions. Jack believes Tristessa truly understands the law of Karma (Kerouac 1992, 23), and that to the Buddhist life is fundamentally conceptualized as suffering (Charters 1986, 225). He describes her "long sad eyelids, and Virgin Mary resignation, and peachy coffee complexion and eyes of astonishing mystery with nothingbut-earth-depth expressionless half disdain and half mournful lamentation of pain" (Kerouac 1992, 8). Furthermore, he states "her face is so expressive of the pain and loveliness that went no doubt into the making of this fatal world" (Kerouac 1992, 52). Jack constantly idealizes Tristessa, transferring onto her a preponderance of religious metaphors. In several places he calls her "the Virgin Mary of Mexico" (Kerouac 1992, 11), "the majestic mother of lovers" (Kerouac 1992, 12), "a Madonna" (Kerouac 1992, 22), as well as "holy" (Kerouac 1992, 22) and "an angel" (Kerouac 1992, 57). He says she will depart as a saint, "cause of her further rebirth [...] straight to her God" (Kerouac 1992, 22-23).

On the other hand, Tristessa represents to Jack a certain measure of prestige. He wishes to possess her and parade her before his friends: "She is such a beautiful girl, I wonder what all my friends would say back in New York and up in San Francisco" (Kerouac 1992, 10). He 
imagines her wearing fancy clothing from New York department stores, while in Mexico she is "reduced to impoverished Indian Lady gloomclothes" (Kerouac 1992, 11). Initially, he fears her in fact; in his dreams she appears as a thief and makes him wonder: "Do you know women as well as you think you do?" (Kerouac 1992, 16). It seems to him she is the "evil Indian Joe of Huckleberry Finn, plotting my demise" (Kerouac 1992, 18), but realizes after all that she is "Sympaticus Tristessa with her heart a gold gate, I'd first dug to be an evil enchantress" (Kerouac 1992, 58). Kerouac writes: "I can picture myself and Tristessa waking up in our nuptial madbed of blankets and dogs and cats and canaries [...] she shoots me in or I shoot myself in a big bang of waterycolored poison straight into the flesh of your arm" (Kerouac 1992, 49).

Ultimately, the protagonist admits he is in love with her, but not in a sexual way as he happens to be experimenting with celibacy. Kerouac a year later described this phase as "some silly ascetic or celibacious notion that I must not touch a woman" (Kerouac 1992, 65). ${ }^{5}$ He appreciates her letting him live life in peace and demanding nothing of him, which is a consequence of the fact she is struggling with heavy addiction, and thus in no position to develop possessive feelings towards him being herself possessed by substance abuse. Although he loves her ("I love her, I fall in love with her" (Kerouac 1992, 22)), he at the same time wishes to abandon her: "I love her but I want to leave" (Kerouac 1992, 22), a highly typical internal tension of Kerouac's autobiographical literary characters.

Jack Duluoz is at that time undergoing his spiritual phase, stating: "I have sworn off lust with women [...] - I want to enter the Holy Stream" (Kerouac 1992, 22). He says he loves her "with all my heart", and yet: "I'm holding myself back" (Kerouac 1992, 22). In his spirituality he states men and women forgive one another's blunders and mistakes "and go their own holy ways to death" (Kerouac 1992, 23). Further, he claims: "I can feel the spirit enter the room as she stands, waiting with her finger pointed up, on her spread legs, confidently, for her Lord to pay her back -" (Kerouac 1992, 56-57). He admires her insight into the essence of life: "Her Enlightenment is perfect" (Kerouac 1992, 57). Ultimately, Jack realizes he cannot marry Tristessa because he is too impoverished himself, because she is marrying Bull, and since "I'd have to be a junkey to live with Tristessa, and I can't be a junkey" (Kerouac 1992, 93). In the final analysis, an addicted Mexican of native heritage is not suitable for marriage because "Jack is again straying too far away from his middle-class convictions” (Phelan Lyke 1991, 67).

When Jack realizes his relationship with Tristessa is disintegrating, he attributes the blame to his pathological attachment to his mother, stating "I've screwed everything up with the mama again, Oedipus Rex, I'll tear out my eyes in the morning [...], I'm always the King sucker who was made out to be the positional son in woman and man relationships [...], I'm always in the way for momma and poppa - when am I gonna be poppa?” (Kerouac 1992, 93)

Kerouac's relationship with Esperanza Villanueva was supposedly mostly non-sexual due to his then-commitment to celibacy as part of Buddhist doctrine, his morphine consumption, and chronic pain due to inflamed veins (Gifford and Lee 1978, 191). In the novel the narrator mentions only kissing: "Tristessa kisses me gently on the lips, the softest, justtouchingest kiss in the world" (Kerouac 1992, 75). He admits he wishes to sleep "next to Tristessa" (Kerouac 1992, 77), but the sexual act never occurs as he elevates her to the level of a saint, spiritually invaluable and physically untouchable. In reality, it appears Kerouac did get physical with Esperanza Villanueva but ultimately crossed this part out of the manuscript on the advice of Lucien Carr's wife, who told him it would have ruined the novel (Clark 1984, 150). 


\section{The Racial Otherness of Female Characters in Kerouac's Novels}

Des Forges (2015) and Collopy (2016) critically analyse the relationship of the narrator protagonist from the novel On the Road (1957) with the Mexican woman Beatrice (or Bee) he meets in California, characterizing it as problematic since it is limited to the admiration of her racial or ethnic Otherness, with frequent allusions to her skin tone as pretty due to its dark pigmentation, entailing little beyond the widespread literary practice of reducing people of colour to their exoticism. Even worse: he equates the colour of Bee's skin with her sexuality, presupposing that non-white women possess the primitivism of uncivilized sexual urges $-\mathrm{a}$ thoroughly racist prejudice on its own. In his confrontation with the despondent situation of American social minorities, Kerouac constantly romanticizes their misery through his protagonists, rather than admitting - let alone examining - how the normalized American hegemony is pushing racial minorities into a dead end, engendering their downward spiral.

Similarly representative is the double (romanticized-racist) view on racial diversity in the novel The Subterraneans. On the one hand, the protagonists sees in Mardou "an Indian warmth", "affection not only from the Indian in you but because as part Negro somehow you are a first, the essential woman, and therefore the most, most originally most fully affectionate and maternal [...], some lost American addition and mood with it", while on the other stating: "every time I see a Mexican gal or Negress I say to myself, 'hustlers, they're all the same, always trying to cheat and rob you" (Kerouac 2018, 103).

Kerouac wrote The Subterraneans before the civil rights movement was in full stride, and when relations between whites and blacks were still segregated. Any support of whites for Negro organizations was viewed as indicative of communist activity; a curiously absurd outlook from the European perspective. The events in the novel The Subterraneans (published in 1958) take place in the summer of 1953 , the work produced in three nights of frenetic typing in October that year, after Kerouac's split from the "black beauty" Alene Lee (Mardou Fox in the novel). Notably, with the exception of Bob Kaufman and Amir Baraka, the members of the Beat Generation were all white. It is thus unusual for the "subterranean" Alene Lee to have moved so freely in white circles as a young woman of colour. At any rate, Kerouac had little insight into the realities of her situation.

Hipkiss $(1976,8)$ claims that the novel expresses both Kerouac's enthusiasm as well as aversion to women of colour. Rexroth (1958: 23) states Kerouac's novel depicts "racism in reverse" and that "seldom has a man understood a woman less". French $(1986,47)$ considers Leo Percepied to be a male chauvinist, a racist and a homophobe. The first impression of Leo at the outset of the novel is that of an egocentric - he is not interested in Mardou as a sovereign person, but rather as an apparently helpless yet attention-catching "Negro" woman: "a poor subterranean beat Negro girl with no clothes on her back worth a two penny" (Kerouac 2018, 100). When he first lays eyes on Mardou, Leo describes her as "dark, you could barely see her in the dim street" (Kerouac 2018, 23), yet the sight of her "made me think, 'By God, I've got to get involved with that little woman' and maybe too because she was Negro" (Kerouac 2018, 22). The depiction of Mardou Fox is typically ethnocentric: her legs and eyes are described as dark, her face soft and brown, Leo patronizingly describes her as a "little thin brown woman disposed to wear dark clothes, poor beat subterranean clothes" 
(Kerouac 2018, 30). He uses diminutive descriptors and considers her lovely, while at the same time comparing her to a snake leading him into temptation. He compares her locution to a speech "I'd never heard before except in certain rare girls of course white so strange". Her voice reminds him of "the cool sound of bop singers" (Charters 1973, 194), a trait he finds especially fascinating.

Leo's perception of Mardou is influenced by his racist prejudice; the fear of a black woman stealing his heart: "she was really a thief of some sort and therefore was out to steal my heart, my white man heart, a Negress sneaking in the world sneaking the holy white men for sacrificial rituals" (Kerouac 2018, 63). Later he says "she'd thieve my soul and eat it" (Kerouac 2018, 63). When Kerouac's alter ego, Leo Percepied, wakes up on an August morning for the first time next to the sleeping Mardou, realizing he has been sharing a bed with a "Negro Woman", he experiences "almost revulsion" and thinks: "what a beast I am for feeling anything near it, grape little sweet-body naked on the restless sheet soft the night-before excitement" (Kerouac 2018, 35). In the morning he is inclined to go home and continue his writing in solitude. The description of the just-awoken Mardou reflect his profound racial prejudice: though he finds her erotic and alluring, he wilfully exoticizes her, establishing the relation between colonizer and colonized. The narrator personally uses the dominating expressions conquest and conquered, as if he were invading/colonizing the object of his desire, with a focus on his own emotions and little regard for the humanity of the loved female as a person; he engages merely with her exterior or physical nature:

I got up and begun to dress, apologize, she lay like a little mummy in the sheet and cast the serious brown eyes on me, like eyes of Indian watchfulness in a wood, like with the brown lashes suddenly rising with black lashes to reveal sudden fantastic whites of eye with the brown glittering iris centre, the seriousness of her face accentuated by the slightly Mongoloid as if of a boxer nose and the cheeks puffed a little from sleep, like the face on a beautiful porphyry mask found long ago and Aztecan. [...]. The adolescent cocksman having made his conquest barely broods at home the loss of the love of the conquered lass, the black-lash lovely [...]. (Kerouac 2018, 36)

As an emancipated woman, Mardou tells Leo at the start of their relationship that she wishes to be independent. Leo at first mythologizes their romantic involvement, characterizing them as an Adam and Eve, while she states "don't call me Eve" (Kerouac 2018, 116). Leo imagines appearing in public with her might protect Mardou from the "Negro fear of American society" (Kerouac 2018, 80), to which she replies he "understands nothing". Evidently that is correct, since Leo characterizes her fear of potential racist violence as "her little-girl fear so cute, so edible" (Kerouac 2018, 81). Later he admits that the love relationship with Mardou is to him a secondary matter, since the only thing he considers vital is work (writing): "at the time work, work was my dominant thought, not love", in which he even entertains himself a victim, continuing with these words: "not the pain which impels me to write this even while I don't want to, the pain which won't be eased by the writing but heightened" (Kerouac 2018, 36).

Explicitly, he mentions his racist doubts in relation to his unease over living with a woman of colour: "Mardou's a Negro, naturally not only my mother but my sister whom I may have to live with some day and her husband a Southerner and everybody concerned, would be 
mortified to hell" (Kerouac 2018, 60). He contemplates life in some kind of Faulknerian home in the American south, worried about "what would they say if my mansion lady wife was a black Cherokee" (Kerouac 2018, 60). Further, he even writes of his "white ambition thoughts or white ambition daydreams" and confesses he felt like he "saw some kind of black thing I've never seen before hanging, like it scared me" (Kerouac 2018, 60). Apprehensively, he examines her body, establishing "it wasn't anything pernicious and pizen juices but just blue dark as in all kinds of women and I was really and truly reassured to actually see and make the study with her" (Kerouac 2018, 60). Leo's racism is most directly expressed in his sentiments while making love to Mardou, when he makes the following commentary:

fearing secretly the few times I had come into contact with the rough stubble-like quality of the pubic, which was Negroid and therefore a little rougher, tho not enough to make any difference, and the insides itself I should say the best, the richest, most fecund moist warm and full of hidden soft slidy mountains, also the pull and force of the muscles being so powerful she unknowing often vice-like closes over and makes a dam-up and hurt. (Kerouac 2018, 87)

Alongside Mardou's dark skin, Kerouac's alter ego is fascinated by her partly Native American heritage. He believes that Mardou's father, an Iroquois Native American of the Cherokee lineage, had gone through far worse experiences than she did, and that her "psychoanalyticinduced anxieties" (Kerouac 2018, 37) cannot compare with the great calamities of her father's life. According to Ann Charters $(1973,42)$, Alene Lee reminded Kerouac of Neal Cassady: both had very difficult childhoods, though Kerouac chauvinistically believes her mental anguish cannot compare to Cassady's, dispossessing her from the capacity to experience psychological suffering to the same extent felt by a man.

According to William Russel $(1962,62)$, Kerouac failed to transcend white chauvinism and considered black inferiority as a specific kind of contemporary noble savagery. The narrator of The Subterraneans admits he treated Mardou unfairly, since her love then meant to him "no more than that I had a nice convenient dog chasing after me" (Kerouac 2018, 66), envisaging her as a Native American woman following him around the slums of Mexico City, where he imagined the two might coexist: "my real secretive Mexican vision of her following me down dark dobe streets of slums of Mexico City not walking with me but following, like Indian women" (Kerouac 2018, 66). Kerouac's discourse, in short, reveals itself as consistently dominating and colonizing, macho and racist. To him, Mardou is not foreign and inferior merely on account of being a woman, but something to be compared to other races, or even an animal.

Tristessa from the second novel is far more profoundly idealized by Jack Duluoz. The morphine addicted Mexican woman is considered by the writer's alter ego to be spiritually profound, even genuinely idiosyncratically Buddhist, which he attributes to her suffering as the source of "holiness". Here, too, we witness Kerouac's typical projection of personal ideas. He describes her as the "Azteca, Indian girl with mysterious lidded Billy Holliday eyes and [...] great melancholic voice" (Kerouac 1992, 8), framing her native heritage as Other by stating: "This just made her more exotic" (Kerouac 1992, 9). 


\section{Conclusion}

From the perspective of the post-colonially oriented New Historicist reading, the novels under scrutiny in this article offer an extraordinary source of meanings and with that ever-new interpretations arising from contrasting the past with the present. The two novels offer plentiful evidence to support the thesis that Kerouac's discourse is monologic or undifferentiated. The analysis of the novels reveals that colonialist discourse fails to be confronted with an opposite pole, a true expression of the voice of the Other (ethnic minorities and women), which would generate a dialogical process within the author's discourse and result in truly subversive art. Kerouac's capacity to empathize with the experience of the Other is naive and conceited in the sense that he wishes to simply further confirm his own counter-cultural status with his contrived understanding of what is, in truth, a thoroughly colonised subject, revealing his underlying dominating and colonialist position.

Kerouac's textual and contextual discourse reveal an entrenched undercurrent of misogyny, alongside traditional sexist conceptions of his time. The two women in the novels may indeed be the central objects of desire of their male protagonists, but they are characterized in a markedly subjective manner, through the instrumentalizing gaze of the male, objectifying narrator, the author's alter ego, who exploits the women for his own self-discovery, experimentation, experience, projection of ideas or simply the satisfaction of his needs. Kerouac's objectifying, patriarchal narrative is reflected in his one-dimensional presentation of the female characters, who are not explored from the point of inner idiosyncratic experiential or spiritual life, but reduced instead largely to the curious or alluring physical, with disregard to their inner experiential states or the surrounding systemic social conditions. In short, it would be correct to state that the women in Kerouac's novels is thoroughly objectivized. The male narrator treats "his" women as if they were prestigious trophies to be desired and possessed, and then characteristically discards them "after use" like redundant objects.

Kerouac's ideal is a self-sacrificing woman, a metaphoric embodiment of the Virgin Mary, who feels boundless love and compassion for the troubled male. The ideal Beat Generation female figure was one fostering an atmosphere in which the men might dedicate themselves exclusively to their art, while she demands nothing for herself and does not interfere in their social lives, being at the same time a passionate lover and yet perpetually innocent. The discourse of Kerouac's autobiographical protagonists proves he granted himself not only personal freedom, but also irresponsibility, naiveté, even childishness. He was afraid not just of being tied down to a woman's "nest" (which he, on the other hand, willingly accepted in his relationship with his mother), but also of being charmed and dominated by a female. He expected from his women a maternally instinctive relationship: they were supposed to understand his wishes, needs and expectations. He pursued women that did not demand responsibility from him, and did not interfere with his drinking buddies and their maleoriented spaces. These conditions are met, partly and only at the start of their romantic relationships, by both the black Mardou Fox from The Subterraneans (1958), as well as the Native American Tristessa from Tristessa (1960). When the two women no longer fulfil the whims of the protagonist narrators, Kerouac's two alter egos, Leo Percepied and Jack Duluoz, both return to the Kerouac female "ideal": his own mother Gabrielle waiting for him in the 
safe haven of the family home. Upon his final breakup with Mardou, Jack leaves for the train station, crying, and has a vision of his mother's countenance and voice speaking out: "Pauvre ti Leo, pauvre ti Leo, tu souffri, les hommes souffri tant, [...] j'va't prendre soin, j’aim'ra beaucoup t'prendre soin tous tes jour mon ange." (Kerouac 2018, 111)

\section{References}

Cassady, Carolyn. 1987. "Life With Jack and Neal." In The Beat Vision, edited by Arthur and Kit Knight, 29-51. New York: Paragon.

Charters, Ann. 1986. Beats \& Company: A Portrait of a Literary Generation. New York: Doubleday \& Company.

Clark, Tom. 1984. Jack Kerouac. New York: Harcourt.

Collopy, Margaret. 2016. “The Irony of Racial Romanticism in Kerouac's Beat Generation.” Painting Bohemia, May 12, 2016. http://paintingbohemia.org/culturalstudies/race-ethnicity/the-irony-of-racial -romanticism-in-kerouacs-beat-generation.

Des Forges, Mariana. 2015. “Why Jack Kerouac Is Still Relevant.” Sonder Magazine, September 24, 2015. https://sondermag.wordpress.com/2015/09/24/why-jack-kerouac-is-still-relevant-for-all-the-wrong -reasons-mariana-des-forges.

French, Warren. 1986. Jack Kerouac. Boston: Twayne.

Foucault, Michel. 2001. Arheologija vednosti. Ljubljana: Studia humanitatis.

Gallagher, Catherine, and Stephen Greenblatt. 2000. Practicing New Historicism. Chicago: Chicago University Press.

Gifford, Barry, and Lawrence Lee. 1978. Jack's Book. New York: St. Martin's.

Greenblatt, Stephen, 1978. Improvisations of Power. Chicago: University of Chicago Press.

-. 1990. Learning to Curse: Essays in Early Modern Culture. New York: Routledge.

Hipkiss, Robert A. 1976. Jack Kerouac: Prophet of the New Romanticism. Lawrence: The Regents Press of Kansas.

Johnson, Joyce. 1983. Minor Characters. Boston: Houghton.

Keith Sawyer, Robert. 2002. "A Discourse on Discourse: An Archeological Study of an Intellectual Concept.” Cultural Studies 16 (3): 433-56. http://keithsawyer.com/PDFs/discourse.pdf.

Kernev Štrajn, Jelka. 2001. "O Greenblattovih interpretacijah razmerja med Prosperom in Kalibanom: Primer paradigme novega historizma.” Primerjalna književnost 24 (1): 83-99. http://www.dlib.si /stream/URN:NBN:SI:DOC-QUWDOQKI/00a66c59-8301-4f7e-86a2-d233a7a99d80/PDF.

Kerouac, Jack. 1963. “Written Address to the Italian Judge.” Evergreen Review 7 (31): 108-10.

-. 1992. Tristessa. New York: Penguin Books.

-. 2018. The Subterraneans. London: Penguin Books.

Lessa, Iara. 2006. "Discursive Struggles Within Social Welfare: Restaging Teen Motherhood.” The British Journal of Social Work 36 (2): 283-98. https://academic.oup.com/bjsw/article-abstract/36/2/283 /1686262?redirectedFrom=fulltext.

Lipton, Lawrence. 1959. The Holy Barbarians. New York: Messner.

Matajc, Vanesa. 2005. "Novi historizem: kompleksna interakcija v poetiki kulture." Literatura 17 (16768): 81-108.

McDowell, Linda. 1996. "Off the Road: Alternative views of Rebellion, Resistance and 'The Beats'." Transactions of the Institute of British Geographers 21 (2): 412-19. https://doi.org/ 10.2307/622491.

Panish, Jon. 1994. "Kerouac's The Subterraneans: A Study of 'Romantic Primitivism'." Melus 19 (3): 10723. https://doi.org/10.2307/467875.

Phelan Lyke, Patrice. "Female Characters in Jack Kerouac's Fiction." MA thesis, Texas Woman's University. https://twu-ir.tdl.org/handle/11274/9088.

Rexroth, Kenneth. 1958. “The Voice of the Beat Generation Has Some Square Delusions." San Francisco Chronicle, February 16, 1958.

Russel, William, 1962. "Kerouac's The Subterraneans." Mainstream, June 15, 1962. 
Stephenson, Gregory. 1990. The Daybreak Boys: Essays on the Literature of the Beat Generation. Carbondale: Sothern Illinois University Press.

Trudeau, Justin Thomas. 2011. "Specters in the Rear-View: Haunting Whiteness in Jack Kerouac's On the Road." Text and Performance Quarterly 31 (2): 149-68. https://doi.org/10.1080/10462937 .2010.549238. 